\title{
Cytogenetic Biomonitoring in Buccal Mucosa Cells of COVID-19 Patients: Preliminary Findings
}

\author{
THIAGO GUEDES PINTO*, MARIA ESTHER SUAREZ ALPIRE* and DANIEL ARAKI RIBEIRO \\ Department of Biosciences, Institute of Health and Society, Universidade \\ Federal de São Paulo (UNIFESP), Santos, SP, Brazil
}

\begin{abstract}
Background/Aim: COVID-19 may lead to progressive respiratory failure as a consequence of alveolar damage, resulting in death. The aim of this study was to evaluate cytogenetic damage in oral cells of COVID-19 patients by micronucleus assay. Patients and Methods: A total of 11 COVID-19 patients aged $40.7 \pm 9.3$ years $(5$ men and 6 women) were included in this study. For the control group, a total of 15 participants not infected with SARS-CoV2 virus were included. The mean age was $41.6 \pm 6.2$ years (5 men and 10 women). Results: The results showed statistically significant differences $(p<0.05)$ in micronucleated buccal mucosa cells of COVID-19 patients. In addittion, a statistically significant increase in karyolysis and karrhyorexis $(p<0.05)$ was observed in COVID-19 patients compared to control. Conclusion: SARS-CoV-2 virus can induce mutagenesis and cytotoxicity in oral cells.
\end{abstract}

A great number of patients were diagnosed with pneumonia in Wuhan, Hubei province, China in the late last year. After proper investigation, it was concluded that pneumonia was caused by a novel coronavirus named SARS-CoV-2, and the disease was called COVID-19 (1). The most common symptoms characterizing COVID-19 are fever followed by, dry cough, fatigue, prostration, myalgia, and dyspnea (2).

Unfortunately, it has been verified that COVID-19 may lead to progressive respiratory failure as a consequence of alveolar damage, resulting in death (1). In an earlier study conducted by Zhou et al. (1), it was demonstrated that the

This article is freely accessible online.

*These Authors contributed equally to this study.

Correspondence to: Professor Daniel A. Ribeiro, Department of Biosciences, Federal University of Sao Paulo, UNIFESP, Rua Silva Jardim, 136, Room 332, Vila Mathias, Santos - SP, 11050-020, Brazil. Tel: +55 1332290156, e-mail: daribeiro@unifesp.br

Key Words: Micronucleus assay, buccal cells, COVID-19 patients. angiotensin-converting enzyme II (ACE2) is the exclusive cell receptor for SARS-CoV-2 in human cells. Furthermore, $\mathrm{Xu}$ et al. have revealed that the RBD domain of SARS-CoV2 demonstrates close interaction with human ACE2 receptors (3). Taken together, these findings suggest that ACE2 receptors play a pivotal role in the molecular mechanisms underlying the pathogenesis of SARS-CoV-2 infection. Therefore, the expression as well as the distribution of the ACE2 receptors in human cells and/or tissues may indicate important infection routes of SARS-CoV-2.

It has been hypothesized that ACE2 receptors are present in oral tissues, such as the tongue mucosa, buccal cells, and gingival tissue (2). A previous study conducted by Nakamura et al. (2) has postulated that ACE2 receptors are expressed in gingival fibroblasts in vitro. These results are consistent with the fact that other cellular types present in the gingival tissue may express ACE2 receptors as well (4).

It is well estaliblished that genetic damage is responsible for genomic instability that underlies the development of many chronic degenerative diseases. In infectious diseases, micronuclei have been identified as useful biomarkers of cell damage (5). Micronuclei indicate biological events closely associated with genotoxicity allowing for a better understanding of the etiopathogenesis and consequently, for proposing prevention strategies (6). Thus, the identification of micronucleated cells in the oral mucosa of COVID-19 patients may be a useful tool to clarify the biological effects of SARSCoV-2 in epithelial tissues, such as oral mucosa cells.

Thus, the aim of this study was to evaluate cytogenetic damage in oral cells from COVID-19 patients.

\section{Patients and Methods}

Participants. A total of 11 COVID-19 patients aged $40.7 \pm 9.3$ years (5 men and 6 women) were included in this study. The volunteers were selected from the Center of Emergency and Hospitalization in the Sao Vicente city, SP. Brazil. For the control group, a total of 15 not infected participants aged $41.6 \pm 6.2$ years ( 5 men and 10 women) were included in this study. All volunteers were diagnosed with COVID-19 by Real time PCR (SARS-CoV-2 Virus detection) or One Step Rapid Test Covid-19 IgG/IgM. A total of two individuals used 
azithromycin and ivermectin in the experimental group. All individuals (control and experimental groups) were non-smokers, except for one person in the experimental group. Furthermore, no exposure to dental X-ray was monitored in the last month. In addition, no oral lesion was visible at clinical evaluation. However, alcohol consumption was not recorded. All demographic characteristics of the participants of the study are summarized in Table I. The study was approved by the Ethics Committee of the Federal University of São Paulo, UNIFESP, number \#1448/2020. Informed consent was signed by all individuals included in the study.

Micronucleus test on oral mucosal cells. The micronucleus test was performed according to the method described by Andrade et al. (7). For this purpose, exfoliated oral cells from all volunteers were collected. This was achieved by scrapping the right/left cheek mucosa with a moist wooden spatula. After that, oral cells were transferred to falcon tubes containing saline solution, centrifuged (800 rpm) for $5 \mathrm{~min}$, fixed in 3:1 methanol/acetic acid, and spread over glass slide. Later, all slides were stained with the Feulgen/Fast Green method.

Data analysis. All slides were blindly evaluated by using a light microscope at $\times 1000$ magnification to identify the presence of micronucleated cells and metanuclear alterations indicative of cytotoxicity. Micronuclei were scored according to the criteria described by Belien et al. (8) as a parameter of DNA damage (mutagenicity). For cytotoxicity, the following nuclear alterations were considered: pyknosis, karyolysis, and karyorrhexis. Results were expressed as a percentage of total cells examined. This analysis was established in a previous study conducted by our research group (8). A total of 2,000 cells were evaluated per volunteer.

Statistical methods. The Student's $t$-test was used to compare the frequencies of micronucleus and cytotoxicity between the experimental group versus the control group (9). The statistical analysis was conducted using BioStat software, version 5.0 (Maringa, PR, Brazil). The level of statistical significance was set at $5 \%$.

\section{Results}

The results showed statistically significant differences $(p<0.05)$ in micronucleated cells in buccal mucosa cells of COVID-19 patients (Figure 1D, Table II).

When cytotoxicity parameters were evaluated, interesting results were observed. First, pyknosis was not different between the COVID-19 group and the control group (Figure 1A). Nevertheless, karyolysis and karrhyorexis were statistically increased in the COVID-19 group compared to the control group $(p<0.05)$ (Figure 1B and C, Table II).

\section{Discussion}

The aim of this study was to evaluate cytogenetic damage and cell death in buccal mucosa cells from COVID-19 patients as indicators of chromosomal injury and cytotoxicity, respectively. Evaluation was performed using the micronucleus test in buccal cells. To the best of our knowledge, this question has not been previously addressed.
Table I. Demographic characteristics of the participants of the study.

\begin{tabular}{|c|c|c|}
\hline Parameters investigated & $\begin{array}{l}\text { Control group } \\
\qquad(\mathrm{n}=15)\end{array}$ & $\begin{array}{l}\text { COVID-19 patients } \\
\qquad(\mathrm{n}=11)\end{array}$ \\
\hline Mean age & $41.6 \pm 6.2$ & $40.7 \pm 9.3$ \\
\hline Gender (Male/Female) & $5 / 10$ & $5 / 6$ \\
\hline Medicines & - & $\begin{array}{l}2 \text { (azithromycin } \\
\text { and ivermectin) }\end{array}$ \\
\hline Dental X-ray & - & - \\
\hline Mouthrinse & - & 1 \\
\hline Smoking & - & 1 \\
\hline Illicit drugs & - & - \\
\hline Chemo- or Radiotherapy & - & - \\
\hline
\end{tabular}

SARS-CoV-2 virus is a member of the coronavirus family and affects humans (10). The coronavirus has a simple structure consisting of several structural proteins, such as the envelope protein $(\mathrm{E})$, spike protein $(\mathrm{S})$, transmembrane protein $(\mathrm{M})$, and nucleoprotein $(\mathrm{N})(11)$. Except for the $\mathrm{N}$ protein, the $\mathrm{E}, \mathrm{S}$, and $\mathrm{M}$ proteins promote virus entry into the mammalian cells, and result in viral pathogenesis (10).

To date, there are direct and indirect ways of transmission for SARS-CoV-2. Direct transmission comprises contact with the infected individual's blood, salivary or respiratory droplets, as well as the urine, feces, semen, and tears (12). The signs and symptoms of COVID-19 are categorized into respiratory and systemic manifestations. The most common are fever, cough, and fatigue $(13,14)$. However, there are further manifestations, such as oral mucosal lesions and neurological disorders, for example loss of smell and taste, myofascial pain, and headache. These symptoms have been included in the diagnostic criteria for COVID-19. The oro- and nasopharynx, and the nasal cavities are potential sites for SARS-CoV-2 virus replication $(15,16)$. For this reason, it is interesting to examine if, and to what extent, SARS-CoV-2 virus is able to induce mutagenesis and/or cytotoxicity in oral cells in vivo. Our results indicated high frequencies of micronucleated cells in buccal mucosa cells of COVID-19 patients when compared to the control group. Herein, it is important to highlight that the micronucleus is induced by chromosome breakage or loss. Therefore, the presence of this cytogenetic parameter indicates mutagenicity in epithelial cells as a result of genomic instability. However, the consequences of this situation are unclear and therefore, they must be investigated.

In order to better elucidate the mechanisms by which SARSCoV-2 virus modulates the biological machinery involved cell death, cytotoxicity was also evaluated. Among the parameters chosen for this purpose, pyknosis did not present significant differences between the infected and healthy control groups. However, our results demonstrated a significant increase in karryorhexis and karyolysis in the buccal mucosa of COVID19 patients. These results are novel, and therefore, a subject for 

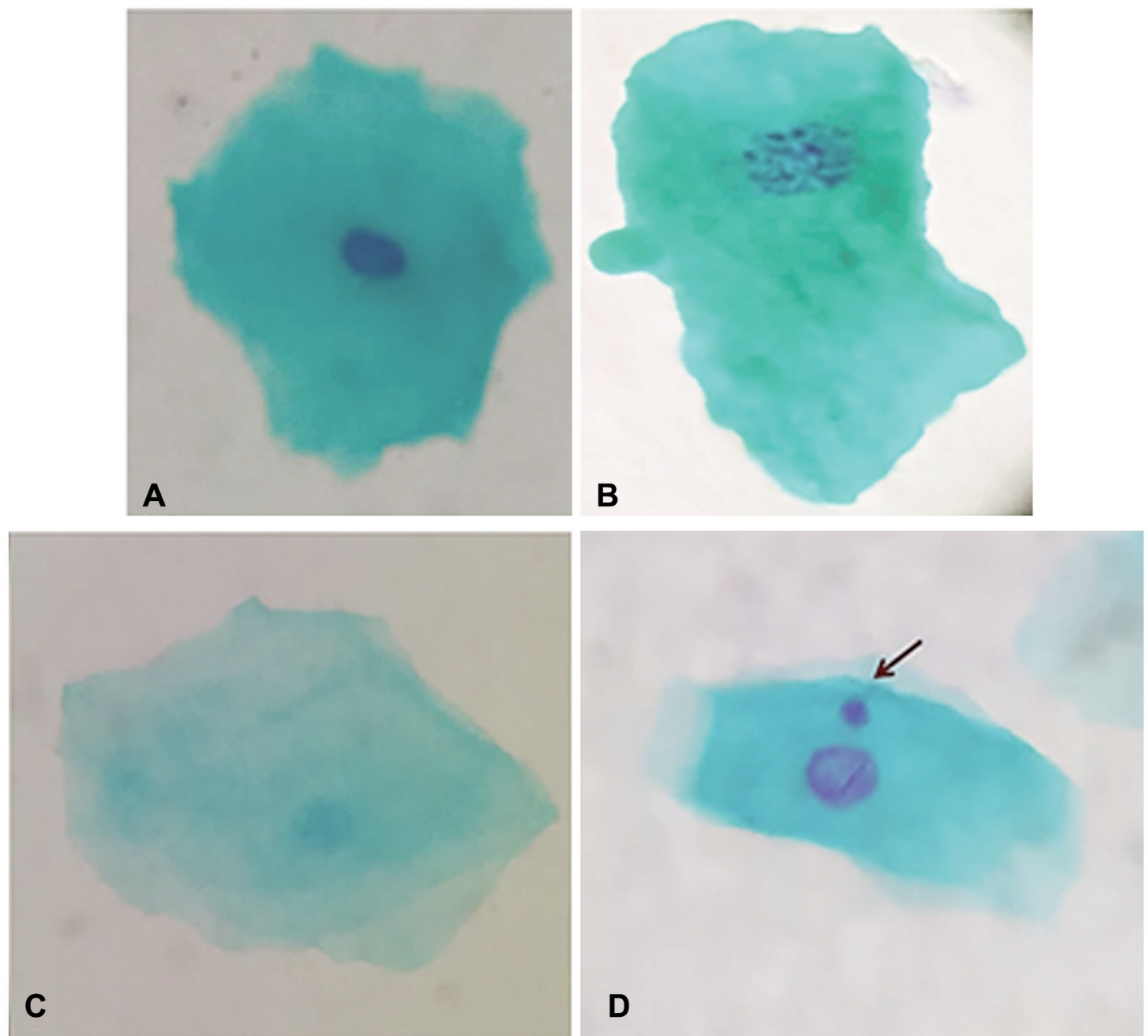

Figure 1. Metanuclear changes in buccal mucosa cells of COVID-19 patients. A: Pyknosis, B: Karrhyorexis; C: Karyolysis, and D: micronucleated cell (arrow). 100x magnification. Feulguen-Fast-Green stain.

Table II. Mean and standard deviation (\% of cells) of cytogenetic parameters (micronucleus, pyknosis, karrhyorexis and karyolysis) in mucosa cells of COVID-19 patients and healthy controls.

\begin{tabular}{lccr}
\hline Groups & Micronucleus & Pyknosis & Karrhyorexis \\
\hline Control $(\mathrm{n}=15)$ & $0.2 \pm 0.5$ & $132.6 \pm 54.6$ & $23.8 \pm 7.9$ \\
COVID-19 patients $(\mathrm{n}=11)$ & $1.4 \pm 1.5^{*}$ & $97.2 \pm 46.4$ & $48.9 \pm 15.5^{*}$ \\
$p$-Value & $p=0.01$ & $p=0.11$ & $p<0.001$ \\
\end{tabular}

${ }^{*} p<0.05$ when compared to the control group.

scientific discussion. It has been established that karryorhexis is closely associated with apoptosis. This is a relevant biological process, in which cell death is genetically controlled for both normal development and tissue homeostasis (17). The second finding is that karyolysis is closely associated with necrosis (17). Despite the fact that the biological mechanisms by which this type of cell death is triggered have not been fully elucidated, it has been postulated that necrosis is induced by a 
high magnitude insult. Overall, our findings show that the SARS-CoV-2 virus induces cellular death in buccal cells either by necrosis or apoptosis. By comparison, Haga et al. postulated that SARS-CoV viruses induce TNF- $\alpha$ expression (18). TNF$\alpha$ is an inflammatory cytokine produced by mononuclear cells during acute inflammation and is responsible for a diverse range of cellular signaling pathways, leading to necrosis or apoptosis (19).

We hypothesized that cellular pathways activated by the interaction of SARS-CoV with ACE2 are involved in viral entry and tissue injury. In fact, oral viral infections are common in clinical practice that are associated with oral lesions. Earlier studies have published some oral symptoms induced by SARS-CoV-2 infection, as for example ulceration and vesicular bullous lesions $(20,21)$. In the oral mucosa, viral infections damage epithelial cells causing acute inflammatory response, presenting with solitary and multiple blisters or even ulcerations (22). Microscopic analysis of biopsies from COVID-19 patients who also presented skin lesions confirmed the vascular ectasia associated with congested vessels, and lymphocytic inflammatory infiltrate (23). Taken together, high ACE2 expression is detected in some cellular types, such as alveolar cells, oropharyngeal mucosa, kidney, gastrointestinal tract, endothelial cells, and oral tissues (16). This finding suggests that such organs and/or tissues with high ACE2-expressing cells must be evaluated individually as much as possible since they are high-risk sites for SARS-CoV-2 infection, especially for mutagenicity and cytotoxicity.

In conclusion, the results of the present study suggest that SARS-CoV-2 virus is able to induce mutagenesis and cytotoxicity in oral cells. However, further studies are needed to better undertand whether SARS-CoV-2 virus promotes mutagenesis associated or not with cytotoxicity in other sites such as the gingiva, tongue, and nasal cells. This information will contribute to the better understanding of the disease as well as the development and authentication of oral diagnostics for COVID-19.

\section{Conflicts of Interest}

All Authors declare no conflicts of interest in relation to this study.

\section{Authors' Contributions}

Conceptualization: MESA and DAR. Data search: TGP and MESA. Formal analysis: TGP, MESA, and DAR. Writing - review \& editing: TGP, MESA, and DAR.

\section{Acknowledgements}

DAR is a recipient from $\mathrm{CNPq}$ (Conselho Nacional de Desenvolvimento Cientifico e Tecnologico, grant number \#001).

\section{References}

1 Zhou P, Yang XL, Wang XG, Hu B, Zhang L, Zhang W, Si HR, Zhu Y, Li B, Huang CL, Chen HD, Chen J, Luo Y, Guo H, Jiang RD, Liu MQ, Chen Y, Shen XR, Wang X, Zheng XS, Zhao K, Chen QJ, Deng F, Liu LL, Yan B, Zhan FX, Wang YY, Xiao GF and Shi ZL: A pneumonia outbreak associated with a new coronavirus of probable bat origin. Nature 579(7798): 270-273, 2020. PMID: 32015507. DOI: 10.1038/s41586-020-2012-7

2 Nakamura T, Hasegawa-Nakamura K, Sakoda K, Matsuyama T and Noguchi K: Involvement of angiotensin II type 1 receptors in interleukin-1 $\beta$-induced interleukin-6 production in human gingival fibroblasts. Eur J Oral Sci 119(5): 345-351, 2011. PMID: 21896050. DOI: 10.1111/j.1600-0722.2011.00850.x

3 Xu X, Chen P, Wang J, Feng J, Zhou H, Li X, Zhong W and Hao $\mathrm{P}$ : Evolution of the novel coronavirus from the ongoing Wuhan outbreak and modeling of its spike protein for risk of human transmission. Sci China Life Sci 63(3): 457-460, 2020. PMID: 32009228. DOI: $10.1007 / \mathrm{s} 11427-020-1637-5$

4 Santos CF, Akashi AE, Dionísio TJ, Sipert CR, Didier DN, Greene AS, Oliveira SH, Pereira HJ, Becari C, Oliveira EB and Salgado MC: Characterization of a local renin-angiotensin system in rat gingival tissue. J Periodontol 80(1): 130-139, 2009. PMID: 19228099. DOI: 10.1902/jop.2009.080264

5 Drummond RL, Rhoden CR, Lubianca Neto JF, Fleck ADS, Padoin RCPK and Amantéa SL: Micronucleus count in nasal epithelial cells from patients with chronic rhinosinusitis and polyps. Braz J Otorhinolaryngol 86(6): 743-747, 2020. PMID: 31285184. DOI: 10.1016/j.bjorl.2019.05.004

6 Znaor A, Fucić A, Strnad M, Barković D, Skara M and Hozo I: Micronuclei in peripheral blood lymphocytes as a possible cancer risk biomarker: a cohort study of occupationally exposed workers in Croatia. Croat Med J 44(4): 441-446, 2003. PMID: 12950148 .

7 Andrade MC, Dos Santos JN, Cury PR, Flygare AC, Claudio SR, Oshima CT and Ribeiro DA: Cytogenetic biomonitoring in buccal mucosal cells from municipal solid waste collectors. Anticancer Res 37(2): 849-852, 2017. PMID: 28179341. DOI: 10.21873/anticanres.11388

8 Beliën JA, Copper MP, Braakhuis BJ, Snow GB and Baak JP: Standardization of counting micronuclei: definition of a protocol to measure genotoxic damage in human exfoliated cells. Carcinogenesis 16(10): 2395-2400, 1995. PMID: 7586141. DOI: 10.1093/carcin/16.10.2395

9 Pereira, CAB: Teste estatístico para comparar proporções em problemas de citogenética. In: Mutagênese, Teratogênese eCarcinogênese. Rabelo-Gay N, Rodrigues MA and MonteleoneNeto R (eds.). SBG, pp. 113-121, 1991 (in Portuguese).

10 Shereen MA, Khan S, Kazmi A, Bashir N and Siddique R: COVID-19 infection: Origin, transmission, and characteristics of human coronaviruses. J Adv Res 24: 91-98, 2020. PMID: 32257431. DOI: $10.1016 /$ j.jare.2020.03.005

11 Neuman BW and Buchmeier MJ: Supramolecular architecture of the Coronavirus particle. Adv Virus Res 96: 1-27, 2016. PMID: 27712621. DOI: 10.1016/bs.aivir.2016.08.005

12 Karia R, Gupta I, Khandait H, Yadav A and Yadav A: COVID19 and its modes of transmission. SN Compr Clin Med: 1-4, 2020. PMID: 32904860. DOI: 10.1007/s42399-020-00498-4

13 Richardson S, Hirsch JS, Narasimhan M, Crawford JM, McGinn T, Davidson KW, the Northwell COVID-19 Research 
Consortium., Barnaby DP, Becker LB, Chelico JD, Cohen SL, Cookingham J, Coppa K, Diefenbach MA, Dominello AJ, DuerHefele J, Falzon L, Gitlin J, Hajizadeh N, Harvin TG, Hirschwerk DA, Kim EJ, Kozel ZM, Marrast LM, Mogavero JN, Osorio GA, Qiu M and Zanos TP: Presenting characteristics, comorbidities, and outcomes among 5700 patients hospitalized with COVID-19 in the New York City area. JAMA 323(20): 2052-2059, 2020. PMID: 32320003. DOI: 10.1001/jama.2020.6775

14 Arentz M, Yim E, Klaff L, Lokhandwala S, Riedo FX, Chong M and Lee M: Characteristics and outcomes of 21 critically ill patients with COVID-19 in Washington State. JAMA 323(16): 1612-1614, 2020. PMID: 32191259. DOI: 10.1001/jama.2020.4326

15 Wang WK, Chen SY, Liu IJ, Chen YC, Chen HL, Yang CF, Chen PJ, Yeh SH, Kao CL, Huang LM, Hsueh PR, Wang JT, Sheng WH, Fang CT, Hung CC, Hsieh SM, Su CP, Chiang WC, Yang JY, Lin JH, Hsieh SC, Hu HP, Chiang YP, Wang JT, Yang PC, Chang SC and SARS Research Group of the National Taiwan University/National Taiwan University Hospital: Detection of SARS-associated coronavirus in throat wash and saliva in early diagnosis. Emerg Infect Dis 10(7): 1213-1219, 2004. PMID: 15324540. DOI: 10.3201/eid1007.031113

16 Herrera D, Serrano J, Roldán S and Sanz M: Is the oral cavity relevant in SARS-CoV-2 pandemic? Clin Oral Investig 24(8): 2925-2930, 2020. PMID: 32577830. DOI: 10.1007/s00784-02003413-2

17 Jeffers L and Webster-Cyriaque JY: Viruses and salivary gland disease (SGD): lessons from HIV SGD. Adv Dent Res 23(1): 7983, 2011. PMID: 21441486. DOI: $10.1177 / 0022034510396882$

18 Haga S, Yamamoto N, Nakai-Murakami C, Osawa Y, Tokunaga $\mathrm{K}$, Sata T, Yamamoto N, Sasazuki T and Ishizaka Y: Modulation of TNF-alpha-converting enzyme by the spike protein of SARS$\mathrm{CoV}$ and ACE2 induces TNF-alpha production and facilitates viral entry. Proc Natl Acad Sci USA 105(22): 7809-7814, 2008. PMID: 18490652. DOI: 10.1073/pnas.0711241105
19 Idriss HT and Naismith JH: TNF alpha and the TNF receptor superfamily: structure-function relationship(s). Microsc Res Tech 50(3): 184-195, 2000. PMID: 10891884. DOI: 10.1002/10970029(20000801)50:3<184::AID-JEMT2>3.0.CO;2-H

20 Brandão TB, Gueiros LA, Melo TS, Prado-Ribeiro AC, Nesrallah ACFA, Prado GVB, Santos-Silva AR and Migliorati CA: Oral lesions in patients with SARS-CoV-2 infection: could the oral cavity be a target organ? Oral Surg Oral Med Oral Pathol Oral Radiol 131(2): e45-e51, 2021. PMID: 32888876. DOI: $10.1016 /$ j.oooo.2020.07.014

21 Farid H, Khan M, Jamal S and Ghafoor R: Oral manifestations of Covid-19-A literature review. Rev Med Virol: e2248, 2021. PMID: 34028129. DOI: 10.1002/rmv.2248

22 Atukorallaya DS and Ratnayake RK: Oral mucosa, saliva, and COVID-19 infection in oral health care. Front Med (Lausanne) 8: 656926, 2021. PMID: 33968961. DOI: 10.3389/fmed.2021.656926

23 Cruz Tapia RO, Peraza Labrador AJ, Guimaraes DM and Matos Valdez LH: Oral mucosal lesions in patients with SARS-CoV-2 infection. Report of four cases. Are they a true sign of COVID19 disease? Spec Care Dentist 40(6): 555-560, 2020. PMID: 32882068. DOI: $10.1111 / \mathrm{scd} .12520$
Received July 6, 2021

Revised July 23, 2021

Accepted July 26, 2021 